\title{
Pengendalian Kualitas pada Proses Produksi Rokok "AF" di PT. IQ
}

\author{
Inung Anggun Saputri, Wiwiek Setya Winahju, dan Diaz Fitra Aksioma \\ Departemen Statistika, Fakultas Matematika, Komputasi, dan Sains Data \\ Institut Teknologi Sepuluh Nopember (ITS) \\ e-mail:diaz_fa@statistika.its.ac.id
}

\begin{abstract}
Abstrak-Industri pengolahan tembakau mempunyai peran penting dalam menggerakkan ekonomi nasional, karena mempunyai multiplier effect yang sangat luas, seperti menumbuhkan industri jasa terkait, dan penyerapan tenaga kerja. PT. IQ merupakan salah satu produsen rokok besar yang terdapat di Surabaya Salah satu produk rokok SKM yang memiliki penjualan paling tinggi adalah rokok "AF". Rokok "AF" merupakan produk rokok kretek filter premium terbuat dari campuran tembakau dan cengkeh terbaik untuk menciptakan cita rasa yang sempurna. Penjualan netto PT. IQ mengalami penurunan sebesar 15,73\% pada tahun 2017 dari tahun sebelumnya. Pengendalian kualitas di PT. IQ hanya dilakukan secara deskriptif dan univariat dimana terdapat kelemahan yaitu kurang efisien terhadap waktu dan tenaga. Oleh karena itu, perlu dilakukan pengendalian kualitas secara statistik untuk mengetahui kebaikan proses secara menyeluruh yang dapat diukur dari kapabilitas proses. Pada penelitian ini digunakan diagram kendali Multivariate Exponentially Weighted Moving Variance (MEWMV) untuk mendeteksi perubahan variabilitas proses dan Multivariate Exponentially Weighted Moving Average (MEWMA) untuk mendeteksi perubahan rata-rata proses. Hasil analisis menunjukkan bahwa pembobot optimum pada peta kendali MEWMV adalah $\omega=0,9$ dan $\lambda=0,9$. Sedangkan pembobot optimum untuk peta kendali MEWMA adalah $\lambda=0,2$. Pada fase satu variabilitas dan rata-rata proses telah terkendali secara statistik dan telah kapabel secara multivariat.
\end{abstract}

Kata Kunci-MEWMA, MEWMV, Multivariat, Peta Kendali, Rokok.

\section{PENDAHULUAN}

$\mathrm{P}$ ERKEMBANGAN sektor industri merupakan salah satu indikator kemajuan suatu negara. Industri pengolahan tembakau mempunyai peran penting dalam meng-gerakkan ekonomi nasional, karena mempunyai multiplier effect yang sangat luas, seperti menumbuhkan industri jasa terkait, penyediaan lapangan usaha dan penyerapan tenaga kerja mencapai 6,1 juta orang terutama di daerah penghasil tembakau, cengkeh, dan sentra-sentra produksi rokok [1]. Tembakau merupakan salah satu komoditas perdagangan industri yang penting di dunia, termasuk Indonesia. Berdasarkan riset Atlas Tobacco, Indonesia menduduki ranking satu dengan jumlah perokok tertinggi di dunia yaitu mencapai 90 juta jiwa pada tahun 2016. Indonesia menempati urutan tertinggi prevalensi merokok bagi ASEAN yaitu sebesar $67,4 \%$ [2]. Oleh karena itu, dengan mempertimbangkan aspek ekonomi industri pengolahan tembakau dikembangkan dengan tidak mengabaikan faktor kesehatan. Industri rokok menjadi sumber penghidupan bagi 6,1 juta orang yang bekerja di Industri rokok secara langsung dan tidak langsung, termasuk 1,8 juta petani tembakau dan cengkeh [3]. Industri rokok juga merupakan salah satu sumber pemasukan negara yang cukup besar dari penerimaan bea dan cukai. Penerimaan bea dan cukai dari industri rokok mengalami kenaikan 10,4\% atau sekitar Rp. 152 trilliun dibandingkan dengan tahun 2016 yaitu sebesar Rp. 142 trilliun [4].

PT. IQ merupakan salah satu produsen rokok besar yang terdapat di Surabaya dan merupakan anak perusahaan PT.WIM Tbk. Produk yang dihasilkan oleh PT. IQ dibedakan menjadi dua kategori berdasarkan proses produksinya yaitu Sigaret Kretek Tangan (SKT) dan Sigaret Kretek Mesin (SKM). Penjualan rokok SKM merupakan penjualan yang paling tinggi yaitu sebesar $77 \%$ dibandingkan dengan rokok SKT [5]. Salah satu produk rokok SKM yang memiliki penjualan paling tinggi adalah rokok "AF". Rokok"AF"merupakan produk rokok kretek filter premium terbuat dari campuran tembakau dan cengkeh terbaik untuk menciptakan cita rasa yang sempurna. "AF" juga merupakan produk rokok reguler yang diproduksi mulai tahun 1960an dan masih menjadi produk reguler andalan bagi PT. IQ.

Berita yang dikutip oleh Market Bisnis menyatakan bahwa PT. IQ mencatatkan penurunan laba bersih sebesar 80,93\% dari Rp. 60,69 miliar pada semester I tahun 2016 menjadi Rp. 11,57 miliar pada semester I tahun 2017. Perseroan mencatatkan penurunan penjualan netto sebesar 15,73\% dari Rp. 902,65 miliar pada semester I tahun 2016 menjadi Rp. 760,68 miliar pada semester I tahun 2017 [6]. Tidak diketahuinya penyebab dari penurunan tersebut menyebabkan perusahaan harus bekerja keras untuk mengejar ketinggalan dari sisi kinerja maupun brand. Perusahaan harus menjaga kualitas produk rokok yang diproduksi.

Pengendalian kualitas statistik sangat diperlukan oleh PT. IQ untuk mengetahui kapabilitas proses produksi rokok "AF". Pengendalian kualitas di PT. IQ dilakukan oleh departemen Secondary Production yang mengukur karakteristik kualitas pada produk rokok "AF". Karakteristik kualitas yang diukur antara lain adalah berat rokok, Pressure Drop (PD), dan diameter rokok. Karakteristik kualitas tersebut yang mempengaruhi performa produk bagi konsumen. Pada proses produksi rokok "AF" dijumpai tiga karakteristik kualitas utama yang sangat penting untuk dimonitor supaya produk yang dihasilkan konsisten sesuai standar. Jika diameter rokok bertambah, maka berat rokok, dan berat hisapan (Pressure Drop) juga akan bertambah. Pada kondisi ini, analisis yang relevan untuk mengontrol proses produksi "AF" adalah peta kendali multivariat. Peta kendali MEWMV (Multivariate Exponentially Weighted Moving Variance) merupakan peta kendali multivariat untuk mendeteksi perubahan variabilitas proses. Sedangkan peta kendali untuk mendeteksi pergeseran mean vektor adalah Multivariate Exponentially Weighted Moving Average (MEWMA). Penelitian sebelumnya di PT. Gelora Djaja dilakukan oleh Mawardi pada produk $D M$ didapatkan hasil bahwa variabilitas dan rata-rata proses telah terkendali dengan peta kendali 
Generalized Variance dan $T^{2}$ Hotelling [7]. Tujuan penelitian ini adalah mendeskripsikan karakteristik kualitas hasil produksi rokok "AF", memonitor variabilitas dan rata-rata proses, dan menilai kebaikan proses produksi rokok “AF".

\section{II.TINJAUAN PUSTAKA}

\section{A. Uji Dependensi (Bartlett's Test)}

Uji Bartlett's Sphericity digunakan untuk mengetahui apakah variabel-variabel saling dependen dengan hipotesis awal $\left(\mathrm{H}_{0}\right)$ adalah $\boldsymbol{\rho}=\mathbf{I}$ (karakteristik kualitas saling independen) dan hipotesis alternatif $\left(\mathrm{H}_{1}\right)$ adalah $\boldsymbol{\rho} \neq \mathbf{I}$ (karakteristik kualitas saling dependen).korelasi bukan merupakan matriks identitas) [8].

Statistik uji yang digunakan dalam uji Bartlett adalah sebagai berikut.

$$
\chi_{\text {hitung }}^{2}=-\left\{n-1-\frac{2 p+5}{6}\right\} \ln |\mathbf{R}|
$$

Keterangan:

$n \quad$ : Banyak data pengamatan

$p \quad$ : Banyak variabel yang digunakan

R : Matriks korelasi

Dengan menggunakan uji hipotesis tersebut, dependensi variabel diketahui apabila nilai $\chi_{\text {hitung }}^{2}>\chi_{\alpha, \frac{1}{2} p(p-1)}^{2}$ atau $p$ value $<\alpha$. Dengan demikian, kesimpulan yang dapat diambil adalah matriks korelasi bukan merupakan matriks identitas, yang berarti bahwa terdapat hubungan antar variabel pada populasi.

\section{B. Distribusi Normal Multivariat}

Pengujian normal multivariat menggunakan Shapiro-Wilk dengan hipotesis awal $\left(\mathrm{H}_{0}\right)$ adalah data berdistribusi normal multivariatdan hipotesis alternatif $\left(\mathrm{H}_{1}\right)$ adalah data tidak berdistribusi normal multivariat. Statistik uji yang digunakan pada pengujian ini adalah sebagai berikut [9].

$$
W^{*}=\frac{1}{p} \sum_{j=1}^{p} W_{z_{j}}
$$

Dengan menggunakan pengujian hipotesis tersebut, data tidak berdistribusi normal multivariat apabila nilai $W^{*}<C_{\alpha ; n ; p}$

\section{Peta Kendali MEWMV}

Diagram kendali MEWMV digunakan untuk men-deteksi secara sensitif terjadinya perubahan variabilitas proses. Pada kasus riil rata-rata dan variabilitas proses dapat berubah selama periode pengamatan. Diagram kendali MEWMV dibentuk dari persamaan berikut [10].

$$
\begin{aligned}
\operatorname{tr}\left(\mathbf{V}_{n}\right) & =\sum_{l=1}^{n} q_{1 l}\left(\sum_{k=1}^{p} x_{1 k} x_{l k}\right)+\sum_{l=1}^{n} q_{2 l}\left(\sum_{k=1}^{p} x_{2 k} x_{l k}\right)+\cdots+\sum_{l=1}^{n} q_{n l}\left(\sum_{k=1}^{p} x_{n k} x_{l k}\right) \\
& =\sum_{i=1}^{n} \sum_{l=1}^{n} q_{i l}\left(\sum_{k=1}^{p} x_{i k} x_{l k}\right)
\end{aligned}
$$

Batas diagram kontrol yang memungkinkan untuk setiap $n$ dan batas kendali berdasarkan $\operatorname{tr}\left(\mathbf{V}_{n}\right)$ sebagai berikut.

$$
\begin{aligned}
& \mathrm{E}\left[\operatorname{tr}\left(\mathbf{V}_{n}\right)\right] \pm L \sqrt{\operatorname{Var}\left[\operatorname{tr}\left(\mathbf{V}_{n}\right)\right]} \\
& p \operatorname{tr}(\mathbf{Q}) \pm L \sqrt{2 p \sum_{i=1}^{n} \sum_{l=1}^{n} q_{i l}^{2}}
\end{aligned}
$$

\section{Peta Kendali MEWMA}

Peta kendali MEWMA digunakan untuk mendeteksi adanya perubahan mean proses. Peta kendali MEWMA merupakan generalisasi dari proses untuk data univariat EWMA yang didefinisikan sebagai berikut [11].

$$
\mathbf{Z}_{i}=\lambda \mathbf{X}_{i}+(1-\lambda) \mathbf{Z}_{i-1}
$$

Titik pengamatan yang diplotkan di diagram kendali adalah sebagai berikut.

$$
\mathbf{T}_{i}^{2}=\mathbf{Z}_{i}^{\prime}\left[\Sigma_{\mathbf{Z}_{i}}\right]^{-1} \mathbf{Z}_{i}
$$

Data dikatakan out of control ketika nilai $\mathrm{T}_{i}^{2}$ lebih besar dari $\mathrm{h}_{4}$. Nilai $\mathrm{h}_{4}$ merupakan batas kendali atas (UCL), didapatkan dari hasil simulasi yang disesuaikan dengan besarnya ARL hingga didapatkan nilai batas kendali atas yang konvergen.

\section{E. Diagram Ishikawa}

Teknik yang berguna untuk analisis ketidaksesuaian lebih lanjut adalah diagram sebab dan akibat (juga dinamakan diagram tulang ikan atau diagram Ishikawa). Diagram sebab dan akibat digunakan untuk melukiskan dengan jelas berbagai sumber ketidaksesuaian dalam produk dan saling hubungannya. Berguna dalam memusatkan perhatian operator, insinyur produksi, dan pimpinan dalam masalah kualitas. Mengembangkan diagram sebab dan akibat yang baik biasanya memajukan tingkat pemahaman teknologi proses [11].

\section{F. Kapabilitas Proses}

Kapabilitas proses merupakan kemampuan suatu pro-ses dalam menghasilkan produk atau jasa yang sesuai dengan kebutuhan syarat dari konsumen atau spesifikasi yang diharapkan.Karakteristik kualitas yang digunakan pa-da penelitian ini adalah sebanyak tiga, maka digunakan indeks performance process secara multivariat dengan mempertimbangkan tidak diketahuinya nilai pembobot dari masing-masing karakteristik kualitas, dapat dihitung dengan menggunakan persamaan berikut ini [12].

$$
\begin{aligned}
& M C_{P}=\sum_{k=1}^{p} W_{k} C_{P}\left(x_{k}\right), \\
& M C_{P K}=\sum_{k=1}^{p} W_{k} C_{P K}\left(x_{k}\right),
\end{aligned}
$$

\section{METODOLOGI PENELITIAN}

\section{A. Sumber Data}

Data yang digunakan pada penelitian ini adalah data sekunder yang didapatkan dari Departemen Research and Development PT. IQ yaitu data hasil produksi "AF" pada bulan Januari sampai dengan November 2017. Data yang digunakan pada Fase I adalah data bulan Januari sampai dengan Agustus 2017, sedangkan pada Fase II menggunakan data bulan September sampai dengan November 2017.

\begin{tabular}{|c|c|c|c|}
\hline $\begin{array}{c}\text { Nama } \\
\text { Variabel }\end{array}$ & Definisi Operasional & Satuan & Batas Spesifikasi \\
\hline Berat Rokok & $\begin{array}{c}\text { Berat rokok setiap } \\
\text { batang }\end{array}$ & gram & $1,36-1,85$ \\
\hline $\begin{array}{l}\text { Diameter } \\
\text { Rokok }\end{array}$ & Lebar lingkaran batang & $\mathrm{mm}$ & $7,76-8,26$ \\
\hline $\begin{array}{l}\text { Pressure } \\
\text { Drop }\end{array}$ & $\begin{array}{l}\text { Daya hidup rokok } \\
\text { selama dihisap }\end{array}$ & $\mathrm{mmWG}$ & $96,42-98,92$ \\
\hline
\end{tabular}
Sistem kerja di PT. IQ terbagi menjadi tiga shift kerja yaitu pagi, siang, dan sore. Subgrup yang digunakan adalah shift dan pada setiap shift diambil satu sampel rokok "AF".

\section{B. Variabel Penelitian}

Variabel yang digunakan pada penelitian ini adalah sebanyak tiga variabel yaitu terdapat pada Tabel 1 berikut ini.

Tabel 1.

Variabel Penelitian 


\section{Struktur Data}

Stuktur dari data yang akan digunakan pada peneliti-an ini ditampilkan pada Tabel 2 berikut ini.

Tabel 2.

Struktur Data Penelitian

\begin{tabular}{cccc}
\multicolumn{4}{c}{ Struktur Data Penelitian } \\
\cline { 2 - 4 } Observasi ke- & \multicolumn{3}{c}{ Karakteristik Kualitas } \\
\cline { 2 - 4 } & $\mathrm{X}_{1}$ & $\mathrm{X}_{2}$ & $\mathrm{X}_{3}$ \\
\hline 1 & $\mathrm{X}_{11}$ & $\mathrm{X}_{12}$ & $\mathrm{X}_{13}$ \\
2 & $\mathrm{X}_{21}$ & $\mathrm{X}_{22}$ & $\mathrm{X}_{23}$ \\
$\ldots$ & $\ldots$ & $\ldots$ & $\ldots$ \\
$\mathrm{n}$ & $\ldots$ & $\mathrm{X}_{\mathrm{n} 2}$ & $\mathrm{X}_{\mathrm{n} 3}$ \\
\hline \hline
\end{tabular}

D. Langkah Analisis

Berikut ini adalah langkah analisis yang digunakan dalam melakukan penelitian

1. Melakukan eksplorasi data secara deskriptif.

2. Melakukan pengujian asumsi yaitu pengujian korelasi antar karakteristik kualitas dan pengujian distribusi normal multivariat.

3. Membuat peta kendali MEWMV (Multivariate Exponentially Weighted Moving Variance).

4. Membuat peta kendali MEWMA (Exponentially Weighted Moving Average).

5. Mengidentifikasi penyebab tidak terkendali dengan diagram ishikawa.

6. Melakukan analisis kapabilitas menggunakan indeks kapabilitas proses.

7. Melakukan pengendalian variabilitas dan rata-rata proses pada fase II dengan menggunakan pembobot optimal yang didapatkan pada fase I.

8. Membuat kesimpulan.

\section{ANALISIS DAN PEMBAHASAN}

\section{A. Karakteristik Data Produksi Rokok "AF"}

Karaktersitik kualitas produk rokok "AF"ini menjadi syarat suatu produk dapat diperdagangkan. Untuk mengetahui gambaran umum mengenai masing-masing karakteristik kualitas pada proses produksi rokok "AF"pada tahun 2017 maka diberikan deskripsi pada Tabel 3 berikut ini.

Tabel 3.

Deskripsi Karakteristik Kualitas

\begin{tabular}{ccccc}
\hline \hline Variabel & Mean & Varians & Min & Maks \\
\hline Berat rokok & 1,5661 & 0,0138 & 1,54 & 1,61 \\
Diameter rokok & 8,0283 & 0,0147 & 7,9 & 8,05 \\
Pressure Drop & 97,672 & 2,873 & 91 & 104,8 \\
\hline \hline
\end{tabular}

Ukuran pemusatan dan penyebaran data proses produksi rokok "AF" pada bulan Januari sampai dengan November 2017 untuk karakteristik kualitas berat rokok, diameter rokok, dan pressure drop ditampilkan pada Tabel 3. Ratarata berat rokok telah berada dalam batas spesifikasi. Tidak terdapat pengamatan yang berada diluar batas spesi-fikasi atas maupun bawah. Rata-rata diameter rokok adalah sebesar 8,0283 mm telah masuk dalam batas spesifikasi dan tidak terdapat data yang keluar dari batas spesifikasi atas maupun bawah. Rata-rata pressure drop pada proses produksi ini adalah 97,672 $\mathrm{mmWG}$ menyebar dengan keragaman data 2,873. Rata-rata pressure drop berada dalam batas spesifikasi, tetapi terdapat data pressure drop yang keluar dari batas spesifikasi atas dan bawah.

\section{B. Pengujian Asumsi Dependensi Variabel dan Distribusi Normal Multivariat}

Pengujian dependensi digunakan untuk mengetahui adanya hubungan antar karakteristik kualitas secara multi- variat. Pengujian dilakukan menggunakan uji Bartlett's Sphericity karena banyaknya karakteristik kualitas lebih dari dua. Hasil pengujian dependensi disajikan pada Tabel 4 berikut ini.

Tabel 4

Hasil Pengujian Dependensi

\begin{tabular}{|c|c|}
\hline Bartlett's Test & Nilai \\
\hline Approx Chi-Square & 26,769 \\
\hline Df & 3 \\
\hline $\mathrm{P}$-value & 0,000 \\
\hline
\end{tabular}

Hasil pengujian dependensi ditunjukkan pada Tabel 4 dan didapatkan nilai statistik uji sebesar 26,769 lebih besar dari critical point Chi-square dengan taraf signifikan $5 \%$ dan derajat bebas 3 yaitu sebesar 7,815. P-value yang diperolehyaitu 0,000 lebih kecil dari taraf signifikan 5\%. Jadi, dapat diambil kesimpulan untuk menolak hipotesis nol yang berarti bahwa karakteristik kualitas saling berhubungan atau dependen. Hasil analisis yang didapatkan sama dengan kondisi lapangan yang menyatakan bahwa jika berat rokok bertambah, maka diameter rokok dan berat hisap atau pressure drop akan bertambah pula. Hal tersebut sesuai dengan hasil analisis yang diperoleh. Oleh karena itu, asumsi dependensi antar karakteristik kualitas telah terpenuhi.

Pengujian normal multivariat dilakukan dengan menggunakan Uji Shapiro Wilk. Hasil pengujian normal multivariat disajikan pada Tabel 5.

Tabel 5.

Hasil Pengujian Normal Multivariat

\begin{tabular}{cc}
\hline \hline Shapiro Wilk Test & Nilai \\
\hline MVW & 0,93002 \\
P-value & $2,2 \times 10^{-16}$ \\
\hline \hline
\end{tabular}

Hasil pengujian normal multivariat dari data proses produksi rokok "AF"dengan karakteristik kualitas berat rokok, diameter rokok, dan pressure drop ditampilkan pada Tabel 5. Nilai statistik uji yang diperoleh adalah 0,93002 kurang dari critical point $C_{0,05 ; 236,3}$ yaitu sebesar 0,9856 . Pvalue yang diperoleh lebih kecil dari taraf signifikan $5 \%$. Jadi, dapat diputuskan untuk menolak hipotesis nol yang berarti bahwa data proses produksi rokok "AF" tidak berdistribusi normal multivariat.

\section{C.Pengendalian Variabilitas Proses dengan Peta Kendali $M E W M V$}

Tabel 7.

Hasil Perhitungan Nilai $\left|\max \operatorname{tr}\left(V_{n}\right)-B K A\right|$ Untuk MEWMV

\begin{tabular}{rrrrrr}
$\omega$ & $\lambda$ & \multicolumn{1}{c}{$\mathrm{L}$} & $\mathrm{Max}(\operatorname{tr}(\mathrm{Vn}))$ & \multicolumn{1}{c}{ BKA } & \multicolumn{1}{c}{ Selisih } \\
0,1 & 0,1 & 2,9000 & 8040,9378 & 7,9656 & 99,1718 \\
0,2 & 0,2 & 3,3086 & 6353,3336 & 7,1068 & 6346,2268 \\
0,3 & 0,3 & 3,6602 & 4864,271 & 5,8632 & 4858,4078 \\
0,4 & 0,4 & 3,9219 & 3573,7501 & 4,5384 & 3569,2117 \\
0,5 & 0,5 & 4,1191 & 2481,7709 & 3,2724 & 2478,4985 \\
0,6 & 0,6 & 4,2715 & 1588,3334 & 2,1541 & 1586,1793 \\
0,7 & 0,7 & 4,3836 & 893,4375 & 1,2364 & 892,2011 \\
0,8 & 0,8 & 4,4590 & 397,0834 & 0,5569 & 396,5265 \\
$\mathbf{0 , 9}$ & $\mathbf{0 , 9}$ & $\mathbf{4 , 4 9 8 4}$ & $\mathbf{9 9 , 2 7 0 8}$ & $\mathbf{0 , 1 4 0 2}$ & $\mathbf{9 9 , 1 3 0 6}$ \\
\hline
\end{tabular}

Peta kendali MEWMV digunakan untuk mengendali-kan variabilitas proses produksi rokok "AF" dimana karakteristik kualitas yang diukur adalah berat rokok, diameter rokok, dan berat hisap atau pressure drop. Berikut merupakan beberapa hasil pengendalian variabilitas menggunakan peta kendali MEWMV yang termuat pada Tabel 7. Pembobot yang digunakan adalah $\omega$ dan $\lambda$ yaitu 0,1 sampai dengan 0,9 dengan semua kombinasinya, yaitu terdapat 81 kombinasi yang dilakukan. Akan tetapi ini hanya ditampil-kan hasil untuk nilai $\omega$ dan $\lambda$ yang sama (Tabel 7). 
Hasil perhitungan untuk menentukan pembobot opti-mum ditunjukkan pada Tabel 7. Pembobot optimum untuk peta kendali MEWMV adalah $\omega=0,9$ dan $\lambda=0,9$ karena me-miliki selisih nilai trace $\mathbf{V}_{\mathrm{n}}$ dengan batas kendali atas yang paling kecil.Peta kendali MEWMV dengan menggunakan pembobot $\omega=0,9$ dan $\lambda=0,9$ disajikan pada Gambar 1 berikut ini.

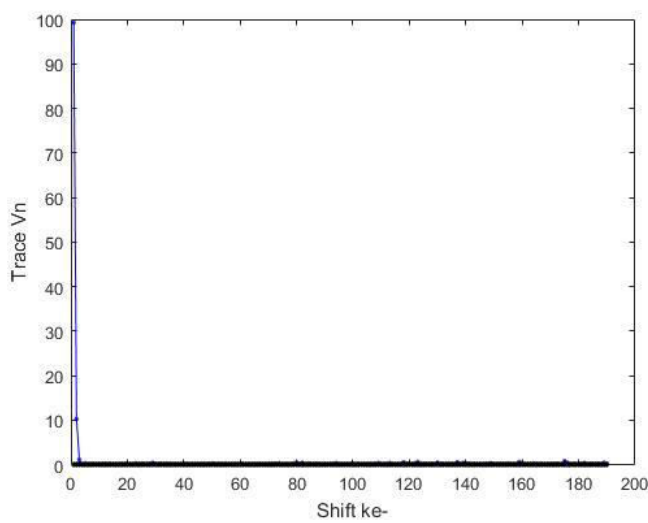

Gambar 1. Peta Kendali MEWMV dengan $\omega=0,9$ dan $\lambda=0,9$.

Peta kendali MEWMV dengan pembobot $\omega=0,9$ dan $\lambda=0,9$ ditampilkan pda Gambar 1 . Sumbu horizontal menunjukkan shift dan sumbu tegak menunjukkan nilai trace $\mathbf{V}_{\mathrm{n}}$ yang dihitung dari Persamaan 3. Berdasarkan grafik tersebut tidak terlihat dengan jelas plot-plot pengamatan dan batas kendalinya. Pada plot pengamatan pertama sampai ketiga terlihat bahwa nilainya sangat tinggi dan dinamakan proses burning up atau keadaan dimana mesin menstabilkan proses yang terjadi setelah digunakan untuk memproduksi jenis rokok lain. Ketiga pengamatan tersebut tidak digunakan untuk menentukan peta kendali MEWMV telah terkendali. Peta kendali MEWMV dinyatakan terkendali apabila tidak terdapat titik pengamatan yang keluar dari batas kendali ketika proses sudah stabil. Oleh karena itu, dibuat peta kendali MEWMV dimulai dari proses yang sudah stabil.

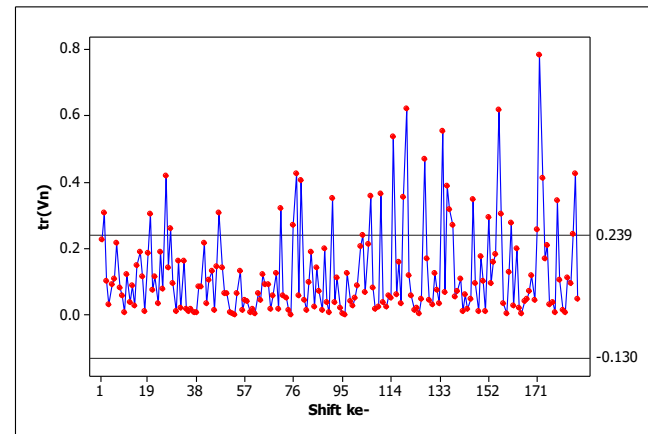

Gambar 2. Peta Kendali MEWMV dengan $\omega=0,9$ dan $\lambda=0,9$ (stabil)

Peta kendali MEWMV dengan pembobot $\omega=0,9$ dan $\lambda=0,9$ dimulai ketika proses telah stabil ditampilkan pada Gambar 2. Terlihat bahwa terdapat 32 plot pengamatan yang berada diluar batas kendali. Langkah selanjutnya ada-lah mencari penyebab pengamatan tersebut keluar dari batas kendali. Berdasarkan hasil analisa pihak PT. IQ, pengamatan yang keluar dari batas kendali dikarenakan salah satu mesin terkadang mengalami trouble dan adanya pergantian shift (pergantian operator). Setelah diketahui penyebab out of control-nya maka selanjutnya adalah mengeluarkan pengamatan yang keluar dari batas kendali. Setelah perbaikan pertama, dibuat peta kendali MEWMV perbaikan ternyata masih terdapat titik pengamatan yang keluar dari batas ken- dali. Variabilitas proses produksi ini terkendali setelah mengalami perbaikan peta kendali MEWMV sebanyak tiga kalidan hasilnya ditampilkan pada Gambar 3 berikut ini.

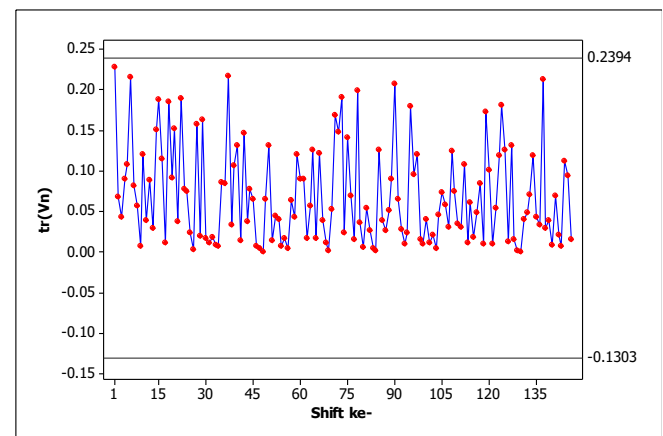

Gambar 3. Peta Kendali MEWMV Perbaikan III.

Peta kendali MEWMV pada proses produksi rokok "AF" setelah dilakukan tiga kali perbaikan ditunjukkan pada Gambar 3. Gambar tersebut menunjukkan bahwa semua plot pengamatan telah berada didalam batas kendali. Oleh karena itu, dapat dikatakan bahwa variabilitas proses pada fase satu telah terkendali secara statistik dengan peta kendali MEWMV.

\section{Pengendalian Rata-rata Proses dengan Peta Kendali MEWMA}

Peta kendali MEWMA digunakan untuk mengendalikan rata-rata proses produksi rokok "AF" dengan karakteristik kualitas yang diukur. Peta kendali MEWMA memiliki pembobot yaitu $\lambda$ dan pada penelitian ini nilai pembobot yang digunakan adalah 0,1 sampai dengan 0,9. Berikut ini merupakan hasil pembuatan peta kendali MEWMA terdapat pada Tabel 8 berikut ini.

Tabel 8 .

Selisih Antara Titik Pengamatan Maksium dan BKA

\begin{tabular}{|c|c|c|c|}
\hline$\lambda$ & $\begin{array}{c}\text { Titik } \\
\text { Maksimum }\end{array}$ & BKA & Selisih \\
\hline 0,1 & 24,8892 & 12,4065 & 12,4826 \\
\hline 0,2 & 20,2375 & 13,3915 & 6,8461 \\
\hline 0,3 & 22,6262 & 13,7935 & 8,8327 \\
\hline 0,4 & 28,2982 & 13,9940 & 14,3042 \\
\hline 0,5 & 33,5317 & 14,1010 & 19,4308 \\
\hline 0,6 & 38,1577 & 14,1590 & 23,9987 \\
\hline 0,7 & 42,1135 & 14,1902 & 27,9234 \\
\hline 0,8 & 45,4028 & 14,2062 & 31,1966 \\
\hline 0,9 & 48,0662 & 14,2136 & 33,8527 \\
\hline
\end{tabular}

Hasil perhitungan untuk menentukan pembobot opti-mum dari peta kendali MEWMA disajikan pada Tabel 8 . Pembobot optimum adalah 0,2 karena memiliki nilai selisih antara nilai pengamatan maksimum dengan batas kendali atas yang paling kecil. Berikut ini merupakan peta kendali MEWMA dengan pembobot 0,2 yang ditampilkan pada Gambar 4.

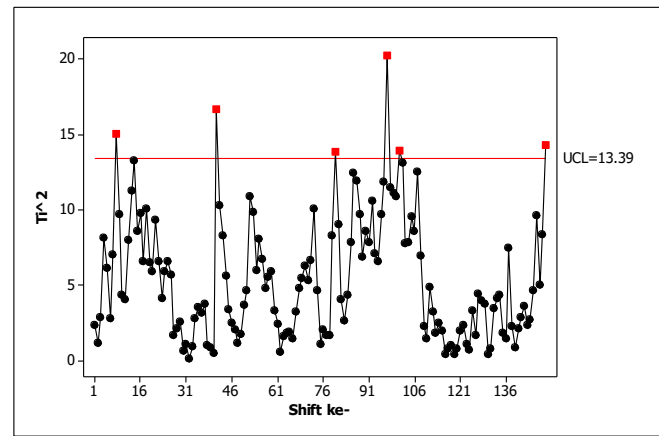

Gambar 4. Peta Kendali MEWMA dengan $\lambda=0,2$. 
Peta kendali MEWMA untuk pembobot optimum terdapat pada Gambar 4. Sumbu horizontal menunjukkan shift dan sumbu vertikal menunjukkan nilai $\mathrm{T}_{\mathrm{i}}^{2}$ yang dihi-tung dari Persamaan 6. Pengendalian rata-rata proses meng-gunakan pembobot $\lambda$ sebesar 0,2 menghasilkan nilai batas kendali atas (BKA) sebesar 13,39. Titik pengamatan $\left(\mathrm{T}_{\mathrm{i}}^{2}\right)$ maksimum untuk pembobot ini 20,2375 yaitu pada pengamatan ke-98. Berdasarkan grafik diatas diketahui pula bahwa dengan pembobot 0,2 terdapat 6 pengamatan yang keluar dari batas kendali atas. Langkah selanjutnya adalah mencari penyebab keenam plot pengamatan tersebut keluar dari batas kendali atas. Penyebabnya adalah mesin mengalami trouble dan adanya pergantian operator. Setelah diketahui penyebabnya, maka pengamatan yang paling jauh dari batas kendali atas dapat dikeluarkan dan dibuat peta kendali MEWMA yang baru seperti pada Gambar 5 berikut ini.

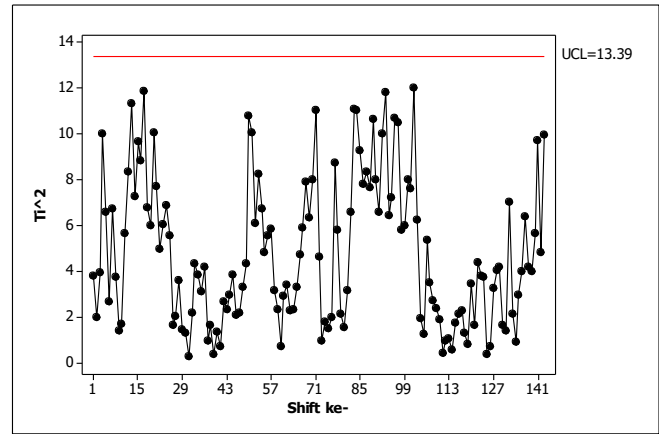

Gambar 5. Peta Kendali MEWMA Setelah Perbaikan $(\lambda=0,2)$.

Peta kendali MEWMA pada proses produksi rokok "AF" pada fase satu setelah mengalami perbaikan ditampil-kan pada Gambar 5. Gambar tersebut menunjukkan bahwa semua plot pengamatan telah berada di dalam batas kendali. Oleh karena itu, dapat dikatakan bahwa rata-rata proses produksi rokok "AF" telah terkendali secara statistik dengan peta kendali MEWMA.

\section{E.Identifikasi Penyebab Out of Control dengan Diagram Ishikawa}

Diagram Ishikawa digunakan untuk menjelaskan penyebab tidak terkendalinya proses produksi rokok "AF" yang digambarkan dalam bentuk tulang ikan terdapat pada Gambar 6. Diagram ishikawa ini diperoleh dari hasil wawancara dan analisa pihak PT. IQ mengenai penyebab proses yang tidak terkendali. Pada diagram ishikawa terdapat lima faktor yaitu material, manusia, mesin, metode, dan lingkungan. Akan tetapi, pada proses produksi ini lingkungan tidak memiliki pengaruh terhadap proses yang tidak terkendali. Pada pembahasan sebelumnya dijelaskan bahwa penyebab utama proses tidak terkendali adalah pada mesin yang sering troubledan pada faktor manusia yaitu adanya pergantian operator. Gambar 6 menunjukkan bahwa faktor lain yang menyebabkan proses tidak terkendali adalah dari metode yaitu proses produksi di PT. IQ menggunakan satu mesin untuk beberapa jenis rokok, misalnya jenis rokok reguler (kretek), mild, dan mentol. Ketiga jenis rokok tersebut memiliki karakteristik yang berbeda. Jadi, pada saat akan memproduksi salah satu jenis rokok harus dilakukan set up mesin. Penyebab lainnya adalah pencampuran bahan baku yang kurang merata. Hal tersebut diakibatkan dari material yang digunakan berasal dari bahan baku yang kurang memenuhi spesifikasi perusahaan.

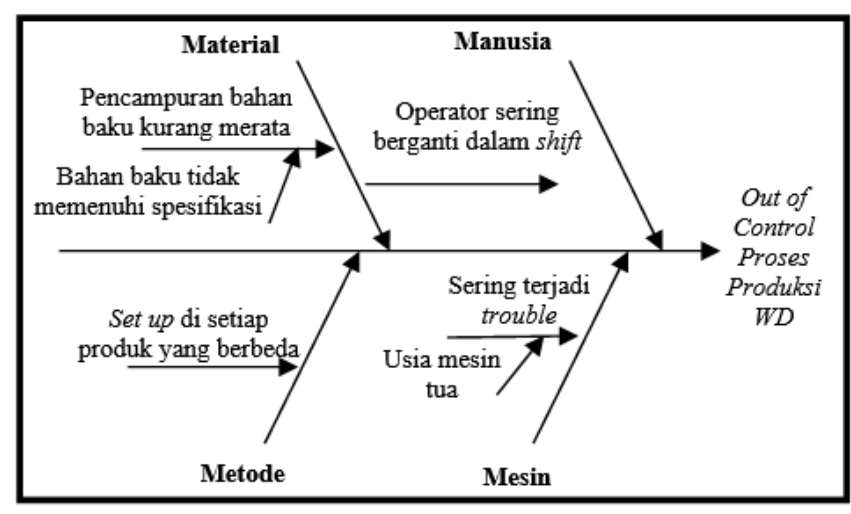

Gambar 6. Diagram Ishikawa Proses Produksi "AF".

\section{F. Kapabilitas Proses Produksi Rokok "AF"}

Kapabilitas proses digunakan untuk mengetahui kinerja proses produksi secara keseluruhan yang diukur dari presisi atau keseragaman dan akurasi atau ketepatan produk yang dihasilkan.

Tabel 9. Kapabilitas Proses Univariat

\begin{tabular}{ccc}
\hline \hline Variabel & $\mathrm{C}_{\mathrm{p}}$ & $\mathrm{C}_{\mathrm{pk}}$ \\
\hline Berat Rokok & 5,95 & 5,00 \\
Diameter Rokok & 7,90 & 7,26 \\
Pressure Drop & 0,21 & 0,20 \\
\hline \hline
\end{tabular}

Hasil analisis kapabilitas pada karakteristik kualitas secara univariat disajikan pada Tabel 9. Pada karakteristik kualitas berat rokok didapatkan nilai $\mathrm{C}_{\mathrm{p}}$ sebesar 5,95 lebih besar dari satu yang berarti bahwa presisi atau keseragaman berat rokok pada proses produksi ini sudah baik. Nilai $\mathrm{C}_{\mathrm{pk}}$ yang dihasilkan adalah 5,00 lebih besar dari satu, berarti bahwa akurasi atau ketepatan telah baik atau sudah sesuai dengan target yang ditentukan. Nilai $\mathrm{C}_{\mathrm{p}}$ pada karakteristik kualitas diameter rokok adalah sebesar 7,90 yang memiliki arti bahwa presisi diameter rokok pada proses ini telah baik. Begitu halnya dengan tingkat akurasi dari diameter rokok ini telah baik dilihat dari nilai $\mathrm{C}_{\mathrm{pk}}$ yaitu 7,26. Pada karakteristik kualitas berat hisap atau pressure drop nilai $\mathrm{C}_{\mathrm{p}}$ yang diperoleh adalah 0,21 kurang dari satu yang berarti bahwa tingkat presisi pressure drop kurang baik atau pressure drop pada proses produksi ini kurang seragam. Hal tersebut telah diindikasikan diawal pembahasan, yaitu pada karakteristik kualitas berat hisap atau pressure drop memiliki keragaman yang besar dan terdapat banyak pengamatan yang berada diluar batas spesifikasi yang ditentukan oleh perusahaan yaitu PT. IQ. Tingkat akurasi karakteristik kualitas berat hisap ataupressure drop ini juga kurang baik ditunjukkan dari nilai $\mathrm{C}_{\mathrm{pk}}$ yang kurang dari satu yaitu 0,20. Perhitungan kapabilitas secara multivariat disaji-kan pada persamaan berikut ini.

$$
\begin{aligned}
& \mathrm{MC}_{\mathrm{p}}=(0,33 \times 5,95)+(0,33 \times 7,90)+(0,33 \times 0,21) \\
& \quad=4,64 \\
& \mathrm{MC}_{\mathrm{pk}}=(0,33 \times 5,00)+(0,33 \times 7,26)+(0,33 \times(0,20) \\
& \quad=4,11
\end{aligned}
$$

Hasil perhitungan kapabilitas secara multivariat menyatakan bahwa nilai $\mathrm{MC}_{\mathrm{p}}$ adalah sebesar 4,64 dan $\mathrm{MC}_{\mathrm{pk}}$ adalah 4,11 dimana kedua nilai tersebut lebih dari satu, hal tersebut menandakan bahwa secara multivariat kinerja proses telah kapabel ditinjau dari tingkat presisi dan akurasi yang telah baik. 


\section{G. Peta Kendali MEWMV dan MEWMA pada Fase II}

Pembobot yang paling optimum dari peta kendali MEWMV adalah $\omega=0,9$ dan $\lambda=0,9$ digunakan pada data fase II dan hasilnya disajikan pada Gambar 7 berikut ini.

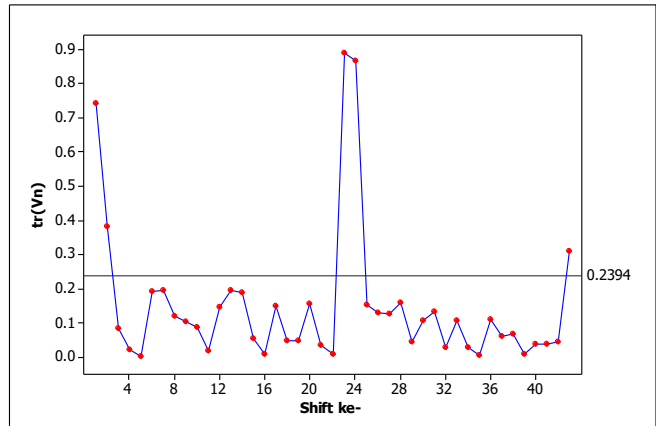

Gambar 7. Peta Kendali MEWMV Fase II.

Peta kendali MEWMV pada fase II proses produksi rokok "AF"ditampilkan pada Gambar 7. Gambar tersebut menunjukkan bahwa variabilitas proses tidak terkendali secara statistik karena masih terdapat 5 titik pengamatan yang berada diluar batas kendali ketika proses sudah stabil.

Nilai pembobot optimum dari peta kendali MEWMA pada fase I yaitu $\lambda=0,2$ yang selanjutnya diterapkan pada fase II. Hasil pembuatan peta kendali MEWMA pada fase II terdapat pada Gambar 8 berikut ini.

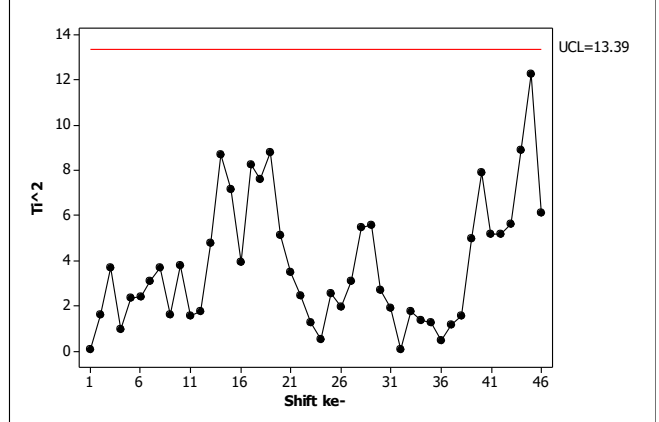

Gambar 8. Peta Kendali MEWMA Fase II.

Pengendalian rata-rata proses pada fase II meng-gunakan peta kendali MEWMA disajikan pada Gambar 8 dan terlihat bahwa semua titik pengamatan berada di dalam batas kendali yang berarti bahwa rata-rata proses produksi rokok "AF" pada fase II telah terkendali secara statistik dengan peta kendali MEWMA.

\section{PENUTUP}

\section{A. Kesimpulan}

Berdasarkan analisis dan pembahasan yang telah dilakukan mengenai pengendalian kualitas pada proses produksi rokok Wismilak Diplomat di PT. IQ, didapatkan kesimpulan rata-rata karakteristik kualitas berat rokok, diameter rokok, dan pressure drop telah berada dalam batas spesifikasi. Tidak terdapat data berat rokok dan diameter rokok yang keluar dari batas spesifikasi, sedangkan pada pressure drop masih terdapat data yang keliuar dari batas spesifikasi. Pada fase I variabilitas dan rata-rata proses produksi rokok "AF" telah terkendali secara statistik menggunakan peta kendali MEWMV dengan pembobot optimal $\omega=0,9 \quad \lambda=0,9$, dan menggunakan peta kendali MEWMA dengan pembobot optimal $\lambda=0,2$. Kapabilitas proses secara univariat menunjukkan bahwa berat rokok dan diameter rokok telah kapabel, tetapi pressure drop tidak kapabel. Secara multivariat, proses produksi telah kapabel. Variabilitas proses pada fase dua tidak terkendali secara statistik, namun rata-rata proses pada fase dua telah terkendali secara statistik.

\section{B. Saran}

Saran yang dapat diberikan kepada PT. IQ adalah sebaiknya memperhatikan faktor atau penyebab yang dapat menimbulkan pengamatan keluar dari batas kendali dan batas spesifikasi terutama pada karakteristik pressure drop yang memiliki keragaman tinggi dan menyebabkan proses tidak kapabel. Pembagian fase sebaiknya didasarkan pada perbaikan yang telah dilakukan oleh perusahaan. Saran untuk penelitian lainnya adalah mempertimbangkan distribusi pada pembobot yang digunakan.

\section{DAFTAR PUSTAKA}

Kementerian Perindustrian, "Gambaran Umum Industri Rokok," www.kemenperin.go.id. [Online]. Available: http://www.kemenperin.go.id/jawaban_attachment.php? $\mathrm{id}=438 \&$ id_t=3154. [Accessed: 26-Feb-2018].

P. Aldino, "Rokok Jerat Kematian dan Kemiskinan," student.cnnindonesia.com. [Online]. Available: https://student.cnnindonesia.com/edukasi/20170306023752-445-

198008/rokok-jerat-kematian-dan-kemiskinan/. [Accessed: 27Feb-2918].

[3] W. Nurhayat, "Begini Pentingnya Industri Rokok Bagi EkonomiRI," finance.detik.com.

[4] D. Wisnu, "Dari Akhir Tahun 2017, Dirjen Bea Cukai Catatkan Penerimaan Pajak Rp 152 Trilliun," jateng. tribunnews.com, 2017.

[5] Wismilak, "Profil Perusahaan."

[6] L. Hendra, "Laba Wismilak Anjlok," market.bisnis.com, 2017.

[7] Y. Mawardi, Pengendalian Kualitas Statistik pada Proses Produksi Diplomat Mild di PT Gelora Djaja. Surabaya: ITS Press, 2016.

[8] D. Morrison, Multivariate Statistical Methods, 3rd ed. New York: Mc Graw Hill Companies, 1990.

[9] J. Alva and E. Estrada, "A Generalization of Saphiro-Wilk's Test for Multivariate Normality," Commun. Stat. Theory Methods, vol. 38, pp. 1870-1883, 2009.

[10] L. Huwang, Arthur, and Chien-Wei, "Monitoring Multi-variate Process Variability for Individual Observa-tions," J. Qual. Technol., vol. 33, pp. 258-278, 2007.

[11] D. Montgomery, Introduction to Statistical Quality Control, 6th ed. New York: John Wiley \& Sons Inc, 2009.

[12] S. Raissi, "Multivariate process capability indices on the presence of priority for quality characteristics," J. Ind. Eng. Int., vol. 5, no. 9, p. 2736, 2009. 